\title{
Deep sternal wound infection after bilateral internal thoracic artery grafting: Insights from a Japanese national database
}

Suguru Ohira, MD, PhD, ${ }^{\mathrm{a}}$ Hiroaki Miyata, $\mathrm{PhD},{ }^{\mathrm{b}}$ Sachiko Yamazaki, $\mathrm{MD}, \mathrm{PhD},{ }^{\mathrm{a}}$

Satoshi Numata, MD, PhD, ${ }^{\mathrm{a}}$ Noboru Motomura, MD, PhD,${ }^{\mathrm{b}}$ Shinichi Takamoto, MD, PhD, ${ }^{\mathrm{b}}$ and

Hitoshi Yaku, MD, $\mathrm{PhD}^{\mathrm{a}}$

\section{ABSTRACT}

Objectives: Despite its survival benefits, bilateral internal thoracic artery (BITA) grafting is not commonly utilized due to concerns over deep sternal wound infection (DSWI). The present study investigated the early outcome of BITA grafting and analyzed the risk of DSWI using a Japanese national database (the Japan Adult Cardiovascular Surgery Database).

Methods: Data from 560 hospitals were used. Between April 2012 and December 2015 , BITA was harvested in 14,249 patients, corresponding to $32.6 \%$ of isolated coronary artery bypass cases. DSWI was defined as a wound infection requiring surgical intervention and/or the administration of antibiotics. Multiple logistic regression analysis was employed to model the risk of DSWI.

Results: The mean age was 67.1 years. The prevalence of diabetes, renal failure, hemodialysis, and liver dysfunction was $51.8 \%, 21.2 \%, 7.8 \%$, and $1.2 \%$, respectively. The incidence of DSWI and operative mortality was 1.6 (234 patients) and $1.6 \%$ (226 patients), respectively. The operative mortality rate in patients with DSWI was $13.7 \%$ (32 patients). The off-pump technique was used in $72.8 \%$, with a conversion rate of $2.5 \%$. Female sex, diabetes mellitus, chronic lung disease, renal failure, liver dysfunction, ejection fraction $\leq 60 \%$, shock status, reoperation, preoperative intra-aortic balloon pump use, and an increased operative time were independent risk factors for DSWI after BITA grafting. The offpump technique did not reduce the risk of DSWI.

Conclusions: The present study showed that early outcomes of BITA grafting were satisfactory regarding DSWI and operative mortality. The current data are informative to predict the risk of DSWI when performing BITA grafting. (J Thorac Cardiovasc Surg 2019;157:166-73)

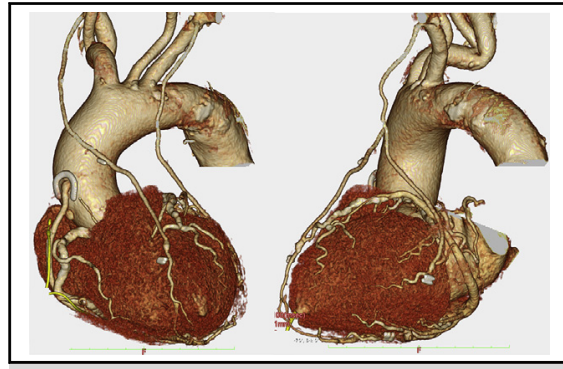

In situ bilateral internal thoracic artery grafting to the left coronary artery.

\section{Central Message}

Bilateral internal thoracic artery grafting in isolated CABG provides an acceptable rate of deep sternal wound infection and mortality in a national database, even with a high rate of BITA use.

\section{Perspective}

The current study, using a Japanese national database with a high rate of bilateral internal thoracic artery grafting, showed satisfactory outcomes regarding mortality and the incidence of deep sternal wound infection. The risk model of deep sternal wound infection developed in the present study is informative when considering bilateral internal thoracic artery grafting.

See Editorial Commentary page 174.

See Editorial page 149.
From the a Department of Cardiovascular Surgery, Kyoto Prefectural University of Medicine, Kyoto, Japan; and ${ }^{\mathrm{b} J a p a n}$ Cardiovascular Surgery Database Organization, Tokyo, Japan.

Received for publication Dec 25, 2017; revisions received May 29, 2018; accepted for publication June 9, 2018; available ahead of print Oct 8, 2018

Address for reprints: Suguru Ohira, MD, PhD, Department of Cardiovascular Surgery, Kyoto Prefectural University of Medicine, 465 Kajii-cho, Kawaramachi-Hirokoji, Kamigyo-ku, Kyoto 602-8566, Japan (E-mail: s-ohira@koto.kpu-m.ac.jp). $0022-5223 / \$ 36.00$

Copyright (c) 2018 by The American Association for Thoracic Surgery

https://doi.org/10.1016/j.jtcvs.2018.06.101
Bilateral internal thoracic artery (BITA) grafting provides survival benefits over single internal thoracic artery (ITA) grafting. ${ }^{1-5}$ However, the rate of utilizing BITA grafting is

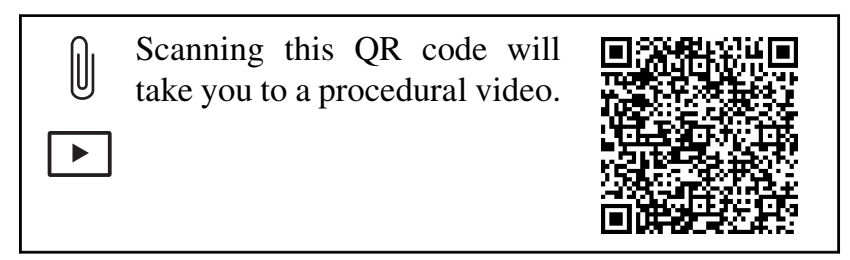




\section{Abbreviations and Acronyms \\ AUC = area under the curve \\ BITA = bilateral internal thoracic artery \\ CABG = coronary artery bypass grafting \\ DSWI $=$ deep sternal wound infection \\ ITA $=$ internal thoracic artery \\ JACVSD = Japan Adult Cardiovascular Surgery \\ Database \\ STS $=$ Society of Thoracic Surgeons}

still low-up to $5 \%$ in the United States ${ }^{6-8}$ and $10 \%$ in Europe $^{9,10}$ - due to concerns over technical difficulties, a longer operative time, and/or higher incidence of wound complications, especially in patients with multiple comorbidities. ${ }^{6,7,11-13}$ Deep sternal wound infection (DSWI) is a devastating complication, associated with mortality, a longer hospital stay, and higher cost of medical care. ${ }^{11,14-16}$ In the Society of Thoracic Surgeons (STS) practice guideline, BITA use should be considered for patients who do not have an excessive risk of sternal complications as a Class IIa indication. ${ }^{17}$ However, it is difficult to predict the risk because the availability of BITA and incidence of DSWI are low,,$^{3,8,9,18}$ and most reports were from single-center studies and lacked statistical power. ${ }^{15,16,18,19}$ The aim of this study was to review the early outcomes and analyze the risks of DSWI after BITA grafting using the Japan Adult Cardiovascular Surgery Database (JACVSD), in which the rate of BITA grafting is more than $30 \%$ of isolated coronary artery bypass grafting $(\mathrm{CABG}) .{ }^{13,20,21}$

\section{PATIENTS AND METHODS \\ Database}

The JACVSD is a national web-based database that incorporates clinical datasets from 560 hospitals in 2015, corresponding to nearly all cardiovascular units in Japan. ${ }^{20,22}$ The data registration project was approved by the institutional review board and informed consent regarding data registration was obtained from all patients at each participating hospital. The data collection form has a total of 255 variables (definitions are available online at www.jacvsd.umin.jp in Japanese), and these are almost identical to those in the STS National Database (http://sts.org). The JACVSD is a web-based data collection system, and each patient's consent was obtained before data entry. The data manager of each participating hospital was responsible for forwarding his or her data electronically to the central office. The rate of data entry was annually monitored in the central office to ensure comprehensive input of the data. The accuracy of submitted data was maintained through a data audit; administrative office members and investigators who previously used the JACVSD for clinical studies randomly visited a participating hospital every month. The present study was approved by the JACVSD Board.

We examined isolated CABG cases between January 1, 2013, and December 31, 2015, using this database, and collected 43,658 isolated CABG cases. The left ITA was harvested in 37,971 patients $(87.0 \%)$. Of these, 14,249 patients ( $32.6 \%$ of isolated CABG) whose BITA had been harvested were retrospectively analyzed based on the intention-to-treat principle.

\section{Surgical Procedures}

ITA was generally harvested with electrocautery and/or an ultrasound scalpel. The method of harvesting ITA as pedicled or skeletonized; pump use; graft arrangement, including in-situ, composite, or aortocoronary bypass grafting; and fashion of anastomosis were determined at each institute. Distal anastomosis was generally performed with 7-0 or 8-0 polypropylene suture. Information on the following was not available in the JACVSD database: ITA harvesting technique, the method of sterilization, chest preparation (eg, hair removal), hemostatic agent application to the sternum, the method of closing the chest, placement of a chest tube, pre- and perioperative administration of antibiotics, and perioperative blood glucose management.

\section{End Points and Definition}

The primary end points were DSWI and operative mortality. DSWI was defined as a wound infection involving muscle, bone, and/or the mediastinum, that meets any of the following conditions: wound opened with excision of tissue or re-exploration of mediastinum, positive culture, or treatment with antibiotics. The definition of operative mortality in JACVSD was exactly the same as in the STS National Database. This includes any patient who died within the index period of hospitalization, regardless of the length of hospital stay, as well as any patient who died after being discharged from hospital up to 30 days from the date of the operation. Stroke was defined as a new neurologic deficit persisting for more than 72 hours. Postoperative renal failure was defined as a patient with newly required hemodialysis or a patient showing a creatinine increase $\geq 2$-fold the preoperative baseline and $\geq 2.0 \mathrm{mg} / \mathrm{dL}$.

Preoperative factors were defined as liver dysfunction (liver enzymes $\geq 100 \mathrm{IU}$, total bilirubin $\geq 1.5 \mathrm{mg} / \mathrm{dL}$, or presence of cirrhosis), renal failure ${ }^{23}$ (the presence of proteinuria, serum creatinine $\geq 1.3 \mathrm{mg} / \mathrm{dL}$, or estimated glomerular filtration rate $<60 \mathrm{~mL} / \mathrm{min} / 1.73 \mathrm{~m}^{2}$ ), or moderate degree of chronic lung disease (forced expiratory volume $1.0<60 \%$, steroid use, oxygen tension $\leq 60 \mathrm{~mm} \mathrm{Hg}$, or carbon dioxide tension $\geq 50 \mathrm{~mm} \mathrm{Hg}$ ).

\section{Statistical Analysis}

Continuous variables are expressed as mean \pm standard deviation. The differences between groups were compared using Student $t$ test for normally distributed continuous data, or the Mann-Whitney $U$ test for nonnormally distributed continuous variables, and using the $\chi^{2}$ test for categorical variables. Data on age and all categorical variables, including sex and 30-day and hospital mortality, were available for all patients. The mode was used in the event of missing data for the following continuous variables: body mass index $(n=1)$, preoperative creatinine $(n=43)$, operative time $(n=3)$, and postoperative creatinine $(\mathrm{n}=40)$. The statistical method applied was the forward stepwise regression model. The odds ratio for DSWI was estimated after adjustment. All variables significant at the $P<.05$ level were entered into the model provided they were present in at least $1 \%$ of the sample (Table E1). We entered the annual case volume of each institute into the model: $\leq 50$ cases as a reference, 51 to 100 cases, 101 to 200 cases, and $\geq 201$ cases. A multivariable forward stepwise logistic regression analysis was then performed. In the case of continuous variables, in which the relationship with the outcome was not linear, we determined cutoff points, such as body mass index. To evaluate model calibration, the Hosmer-Lemeshow test for goodness of fit was applied $(P=.884)$ (Figure 1). The area under the receiver operating characteristic curve (AUC) was used to assess how well the model could discriminate between patients with and without events. AUC $<0.7$ was considered poor, 0.7 to 0.8 was acceptable, and $>0.8$ was excellent. SPSS version 24.0 (IBM-SPSS Inc, Armonk, NY) was used for all analyses.

\section{RESULTS}

\section{Preoperative Characteristics}

Table 1 shows preoperative characteristics. The mean age was $67.1 \pm 9.9$ years. The prevalence of triple-vessel disease 


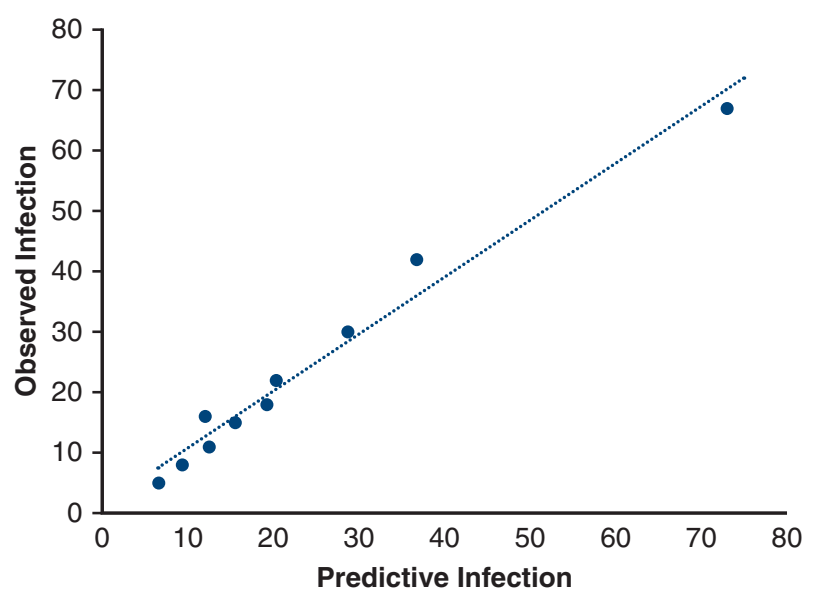

FIGURE 1. Deep sternal wound infection risk model calibration.

and a left main lesion was $78 \%$ and $41.9 \%$, respectively. Diabetes mellitus was diagnosed in $51.8 \%$ of patients ( 7376 out of 14,249). Twenty-three percent of patients had a previous history of percutaneous coronary intervention (PCI).

The prevalence of diabetes mellitus; chronic lung disease; renal failure, including hemodialysis; congestive heart failure; a low ejection fraction; unstable angina; previous myocardial infarction; cardiogenic shock; and reoperation was significantly higher in patients with DSWI. The proportion of female patients was higher in the DSWI group. The rates of using steroids, antiplatelet agents except for aspirin, and an intra-aortic balloon pump were significantly higher in patients with DSWI.

\section{Operative Outcomes}

Of 14,249 patients from whom BITA was harvested, it was utilized in 13,484 patients $(94.6 \%)$ (Table 2). The mean operative time was significantly longer in patients with than without DSWI $(370 \pm 102$ minutes vs $350 \pm 98$ minutes, respectively; $P<.001)$. The median number of distal anastomoses was 3 (mean, $3.5 \pm 1.1$ ) in each group. The great saphenous vein was used in $64.4 \%$ of patients, followed by the gastroepiploic artery $(12.5 \%)$ and left radial artery $(10.0 \%)$. An off-pump procedure was performed in 10,375 patients $(72.8 \%)$, with a conversion rate of $2.5 \%$. The aorta-no-touch technique was used in $46.5 \%$ of off-pump CABG cases.

\section{Postoperative Outcomes}

The total incidence of DSWI was $1.6 \%$ in BITA grafting. In patients with diabetes, the incidence of DSWI was 2.3\% (168 out of 7376). Annual incidences of DSWI after BITA harvesting were $1.6 \%$ in $2013,1.9 \%$ in 2014 , and $1.4 \%$ in $2015(P=.202)$. The 30 -day and operative mortality rates of BITA grafting were $0.8 \%$ and $1.6 \%$, respectively (Table 3). The incidence of reoperation for bleeding of BITA grafting was $1.2 \%$.
The operative mortality rate in patients with DSWI was significantly higher than in the control group $(13.7 \%$ vs $1.4 \% ; P<.001)$. The incidence of morbidities, including reoperation for bleeding, stroke, renal failure, and prolonged ventilation, was significantly higher in patients with DSWI. Patients with DSWI had higher incidences of postoperative atrial fibrillation, pneumonia, urinary tract infection, gastrointestinal bleeding, and readmission. The length of hospital stay was significantly longer in patients with DSWI.

\section{Risk Model}

Logistic regression analysis demonstrated that female sex, diabetes mellitus, renal failure, moderate or greater chronic lung disease, liver dysfunction, shock status, reoperation, ejection fraction $<60 \%$, preoperative intra-aortic balloon pump use, and increased operative time were independent risk factors for DSWI (Table 4). The total number of cases at each center was not a significant risk factor for DSWI. AUC of this risk model was 0.7003 , representing an acceptable discrimination power (Figure 2).

\section{DISCUSSION}

The present study using the JACVSD showed satisfactory early outcomes of BITA grafting with a higher usage rate of BITA in isolated CABG, and a risk model of DSWI was developed. The major reason operators hesitate to perform BITA grafting is concern over DSWI, especially in patients with multiple preoperative risk factors such as diabetes mellitus, a low ejection fraction, lung disease, and chronic kidney disease. ${ }^{11,16,18,19}$ Indeed, the present study showed that the rate of serious postoperative complications, including hospital death and major morbidities, was significantly higher in DSWI patients. Nonetheless, the survival benefits of BITA grafting for these high-risk patients have been reported compared with single ITA grafting. . $^{3-5,13}$ Therefore, an appropriate risk assessment of DSWI is essential to minimize the risk and maximize the long-term benefits derived from BITA use. Furthermore, the current analysis using a national database with high rates of BITA harvesting may provide significant insight beyond that offered by previous studies from leading centers. ${ }^{1-3,5,15}$

The incidence of DSWI in the present cohort $(1.6 \%)$ was acceptable compared with reports of BITA grafting from multiple centers or nationwide cohorts $(1.4 \%-5.2 \%))^{7-9,20}$ In terms of patients with diabetes, the incidence of DSWI receiving BITA grafting is reported to be from 2.9 to $11.6 \%,{ }^{3,13,15,20}$ and in the present study was $2.3 \%$. As for the preoperative characteristics of the present cohort, the prevalence of diabetes $51.8 \%$ in the present cohort vs $18.2 \%-33.3 \%$ in patients who underwent BITA grafting in previous studies), ${ }^{1,6-8,14}$ renal failure $(21.2 \%$ vs $1.7 \%$ $7.7 \%$ in patients who underwent BITA grafting in previous studies) ${ }^{6-8,14,24}$ including chronic hemodialysis $(7.8 \%$ vs $0.5 \%-1.2 \%$ in patients who underwent BITA 
TABLE 1. Patient characteristics

\begin{tabular}{|c|c|c|c|c|}
\hline Characteristics & $\begin{array}{c}\text { All } \\
(\mathrm{N}=14,249)\end{array}$ & $\begin{array}{l}\text { Deep sternal } \\
\text { wound infection } \\
\quad(\mathbf{n}=\mathbf{2 3 4})\end{array}$ & $\begin{array}{l}\text { No deep sternal } \\
\text { wound infection } \\
(\mathrm{n}=\mathbf{1 4 , 0 1 5})\end{array}$ & $P$ value \\
\hline Age $(y)$ & $67.1 \pm 9.9$ & $67.6 \pm 10.7$ & $67.1 \pm 9.9$ & .465 \\
\hline Male & $11,850(83.2)$ & $11,675(74.5)$ & $11,675(83.3)$ & .001 \\
\hline Body surface area $\left(\mathrm{m}^{2}\right)$ & $1.68 \pm 0.18$ & $1.67 \pm 0.20$ & $1.68 \pm 0.18$ & .420 \\
\hline Body mass index & $24.0 \pm 3.5$ & $24.4 \pm 3.8$ & $24.0 \pm 3.5$ & .088 \\
\hline Body mass index $\geq 30$ & $756(5.3)$ & $15(6.4)$ & $741(5.3)$ & .447 \\
\hline Hypertension & $10,981(77.1)$ & $188(80.3)$ & $10,793(77.0)$ & .229 \\
\hline Hyperlipidemia & $9476(66.5)$ & $151(64.5)$ & $9325(66.5)$ & .519 \\
\hline Diabetes mellitus & $7376(51.8)$ & $168(71.8)$ & $7208(51.4)$ & $<.001$ \\
\hline Diabetes with treatment & $6206(43.6)$ & $143(61.1)$ & $6063(43.2)$ & $<.001$ \\
\hline Peripheral artery disease & $2212(15.5)$ & $41(17.5)$ & $2171(15.5)$ & .395 \\
\hline Smoking history & $7715(54.1)$ & $115(49.1)$ & $7600(54.2)$ & .122 \\
\hline Smoking $\leq 1$ mo & $2588(18.2)$ & $44(18.8)$ & $2544(18.2)$ & .798 \\
\hline Chronic lung disease moderate or greater & $272(1.9)$ & $10(4.3)$ & $262(1.9)$ & .008 \\
\hline Renal failure & $3025(21.2)$ & $88(37.6)$ & $2937(21.0)$ & $<.001$ \\
\hline Hemodialysis & $1114(7.8)$ & $41(17.5)$ & $1073(7.7)$ & $<.001$ \\
\hline Creatinine (mg/dL) & $0.90(0.76-1.14)$ & $0.94(0.76-1.74)$ & $0.90(0.76-1.14)$ & $<.001$ \\
\hline Estimated glomerular filtration rate $\left(\mathrm{mL} / \mathrm{min} / 1.73 \mathrm{~m}^{2}\right)$ & $47.1 \pm 25.9$ & $41.9 \pm 24.6$ & $47.2 \pm 25.9$ & .001 \\
\hline Liver dysfunction & $169(1.2)$ & $10(4.3)$ & $159(1.1)$ & $<.001$ \\
\hline Cerebrovascular disease & $1576(11.1)$ & $32(13.7)$ & $1544(11.0)$ & .198 \\
\hline Carotid stenosis & $1089(7.6)$ & $17(7.3)$ & $1072(7.6)$ & .826 \\
\hline Atrial fibrillation & $458(3.2)$ & $13(5.6)$ & $445(3.2)$ & .041 \\
\hline Operation emergent & $524(3.7)$ & $7(3.0)$ & $517(3.7)$ & .574 \\
\hline Congestive heart failure & $3265(22.9)$ & $80(34.2)$ & $3185(22.7)$ & $<.001$ \\
\hline New York Heart Association functional class IV & $784(5.5)$ & $24(10.3)$ & $760(5.4)$ & .001 \\
\hline Shock & $282(2.0)$ & $19(8.1)$ & $263(1.9)$ & $<.001$ \\
\hline Left main disease & $5971(41.9)$ & $95(40.6)$ & $5876(41.9)$ & .683 \\
\hline Triple-vessel disease & $11,109(78.0)$ & $189(80.8)$ & $10,920(77.9)$ & .296 \\
\hline Canadian Cardiovascular Society classification IV & $2302(16.2)$ & $56(23.9)$ & $2091(14.9)$ & $<.001$ \\
\hline Angina & $12,041(84.5)$ & $206(88.0)$ & $11,853(84.5)$ & .132 \\
\hline Unstable angina & $4233(29.7)$ & $86(36.8)$ & $4147(29.6)$ & .017 \\
\hline Percutaneous coronary intervention & 3407 (23.9) & $58(24.5)$ & 3349 (23.9) & .751 \\
\hline Old myocardial infarction & $4661(32.7)$ & 95 (40.6) & $4566(32.6)$ & .010 \\
\hline Ejection fraction $30 \%-60 \%$ & $6173(43.3)$ & $136(58.1)$ & $6037(43.1)$ & $<.001$ \\
\hline Ejection fraction $<30 \%$ & $742(5.2)$ & $15(6.4)$ & $727(5.2)$ & .404 \\
\hline Reoperation & $106(0.7)$ & $5(2.6)$ & $101(0.7)$ & .012 \\
\hline Aortic stenosis & $371(2.6)$ & $6(2.6)$ & $365(2.6)$ & .969 \\
\hline Aortic regurgitation $\geq 2$ & $924(6.5)$ & $14(6.0)$ & $910(6.5)$ & .753 \\
\hline Mitral regurgitation $\geq 2$ & 2087 (14.6) & $47(20.1)$ & $2040(14.6)$ & .018 \\
\hline Tricuspid regurgitation $\geq 2$ & $1055(7.4)$ & $26(11.1)$ & $1029(7.3)$ & .029 \\
\hline Aspirin $\leq 5 \mathrm{~d}$ & $5191(36.4)$ & $82(35.0)$ & $5109(36.4)$ & .656 \\
\hline Other antiplatelet agent $\leq 5 \mathrm{~d}$ & $1161(8.1)$ & $30(12.8)$ & $1131(8.1)$ & .008 \\
\hline Anticoagulant medication $\leq 48 \mathrm{~h}$ & 1517 (10.6) & $29(12.4)$ & 1488 (10.6) & .382 \\
\hline Beta blockers & $4668(32.8)$ & $90(38.5)$ & 4578 (32.7) & .061 \\
\hline
\end{tabular}


TABLE 1. Continued

\begin{tabular}{|c|c|c|c|c|}
\hline Characteristics & $\begin{array}{c}\text { All } \\
(\mathrm{N}=14,249)\end{array}$ & $\begin{array}{c}\text { Deep sternal } \\
\text { wound infection } \\
\quad(\mathbf{n}=\mathbf{2 3 4})\end{array}$ & $\begin{array}{l}\text { No deep sternal } \\
\text { wound infection } \\
\quad(n=14,015)\end{array}$ & $P$ value \\
\hline Steroids & $158(1.1)$ & $6(2.6)$ & $152(1.1)$ & .032 \\
\hline Inotropic agents & $152(1.1)$ & $3(1.3)$ & $149(1.1)$ & 741 \\
\hline Intra-aortic balloon pump & 1915 (13.4) & $55(23.5)$ & $1860(13.3)$ & $<.001$ \\
\hline
\end{tabular}

Values are presented as mean \pm standard deviation, $\mathrm{n}(\%)$, or median (interquartile range).

grafting in previous studies), ${ }^{6,8,15}$ previous percutaneous coronary intervention $(23.9 \%$ vs $3.2 \%-16.7$ in patients who underwent BITA grafting in previous studies), $2,10,15$ and peripheral artery disease $(15.5 \%$ vs $6.5 \%-9.5 \%$ in patients who underwent BITA grafting in previous studies) $)^{1,7,15}$ was higher compared with other reports. Possible reasons are that the mean age was older in the present compared with previous studies (67.1 years vs 56.0-60.1 years), and the above preoperative risks might interact with each other and increase the prevalence. ${ }^{1,6,8,9}$

In the present risk model, 10 variables were identified as predictors of DSWI after BITA grafting with an acceptable accuracy of prediction. Of these, female sex, diabetes mellitus, renal failure, and chronic lung disease have been recognized as major risk factors for DSWI. ${ }^{9,12,16,18}$ Preoperative liver disease is associated with postoperative liver/renal failure, bleeding, and poor wound healing; however, it is not included in the variables of the STS risk score or European system for cardiac operative risk evaluation II. The present study showed that liver dysfunction is a strong risk factor for DSWI after BITA grafting. The preoperative hemodynamic status, such as ejection fraction $<60 \%$, preoperative intra-aortic balloon pump use, and shock status were also identified as independent risk factors for DSWI. These results are reasonable because a low output status has been recognized as a risk factor for infection. ${ }^{18,19} \mathrm{An}$ increase in the operative time is directly associated with an increased risk of DSWI;

TABLE 2. Operative details

\begin{tabular}{|c|c|c|c|c|}
\hline Characteristics & All $(N=14,249)$ & $\begin{array}{c}\text { Deep sternal wound } \\
\text { infection }(n=234)\end{array}$ & $\begin{array}{l}\text { No deep sternal wound } \\
\text { infection }(n=14,015)\end{array}$ & $P$ value \\
\hline BITA harvest & $14,249(100)$ & $234(100)$ & $14,015(100)$ & - \\
\hline BITA use & $13,484(94.6)$ & $225(96.2)$ & $13,249(94.5)$ & .297 \\
\hline Left ITA use & $13,991(98.2)$ & $230(98.3)$ & $13,761(98.2)$ & .907 \\
\hline Right ITA use & $13,698(96.1)$ & $227(97.0)$ & $13,476(96.2)$ & .484 \\
\hline Saphenous vein & $9176(64.4)$ & $161(68.8)$ & 9015 (64.3) & .156 \\
\hline Left radial artery & $1423(10.0)$ & $16(6.8)$ & $1407(10.0)$ & .105 \\
\hline Right radial artery & $244(1.7)$ & $5(2.1)$ & $239(1.7)$ & .614 \\
\hline Gastroepiploic artery & $1783(12.5)$ & $29(12.4)$ & $1754(12.5)$ & .955 \\
\hline Number of distal anastomosis & $3(3-4)$ & $3(3-4)$ & $3(3-4)$ & .755 \\
\hline 2 & $2501(17.6)$ & $41(17.5)$ & 2460 (17.6) & \\
\hline 3 & $5188(36.4)$ & $91(38.9)$ & $5097(36.4)$ & \\
\hline$\geq 4$ & $6560(46.0)$ & $102(43.6)$ & $6458(46.1)$ & .701 \\
\hline Operative time, $\min$ & $351 \pm 98$ & $370 \pm 101$ & $350 \pm 98$ & .002 \\
\hline$\leq 3 \mathrm{~h}$ & $185(1.3)$ & $3(1.3)$ & $182(1.3)$ & \\
\hline $3-4 \mathrm{~h}$ & $1283(9.0)$ & $17(7.3)$ & $1266(9.0)$ & \\
\hline $4-5 \mathrm{~h}$ & 3015 (21.6) & $37(15.8)$ & $2978(21.2)$ & \\
\hline $5-6 \mathrm{~h}$ & $3842(27.0)$ & $56(23.9)$ & 3768 (26.9) & \\
\hline $6-7 \mathrm{~h}$ & 2919 (20.5) & $59(25.2)$ & $2860(20.4)$ & \\
\hline$\geq 7 \mathrm{~h}$ & $3002(21.1)$ & $62(26.5)$ & $2940(21.0)$ & .057 \\
\hline Off-pump & $10,375(72.8)$ & $163(70.0)$ & $10,212(72.9)$ & .274 \\
\hline Conversion from off-pump & $259 / 10,375(2.5)$ & $4 / 163(2.5)$ & $255 / 10,212(2.5)$ & 1.00 \\
\hline Aorta-no-touch & $4820 / 10,375(46.5)$ & $76 / 163(46.6)$ & $4744 / 10,212(46.5)$ & .660 \\
\hline Transfusion & 8922 (62.6) & $169(72.2)$ & $8753(62.5)$ & .002 \\
\hline
\end{tabular}

Values are presented as $\mathrm{n}(\%)$, mean \pm standard deviation, or $\mathrm{n} / \mathrm{n}(\%)$. BITA, Bilateral internal thoracic artery; ITA, internal thoracic artery. 
TABLE 3. Postoperative results

\begin{tabular}{|c|c|c|c|c|}
\hline Outcomes & All $(N=14,249)$ & $\begin{array}{c}\text { Deep sternal wound } \\
\text { infection }(n=234)\end{array}$ & $\begin{array}{c}\text { No deep sternal wound } \\
\text { infection }(n=14,015)\end{array}$ & $P$ value \\
\hline 30-d mortality & $120(0.8)$ & $4(1.7)$ & $116(0.8)$ & .135 \\
\hline Operative mortality & $226(1.6)$ & $32(13.7)$ & $194(1.4)$ & $<.001$ \\
\hline Reoperation for bleeding & $165(1.2)$ & $10(4.3)$ & $155(1.1)$ & $<.001$ \\
\hline Stroke & $207(1.5)$ & $10(4.3)$ & $197(1.4)$ & $<.001$ \\
\hline Prolonged ventilation & $381(2.7)$ & $28(12.0)$ & $353(2.5)$ & $<.001$ \\
\hline Renal failure & $309(2.2)$ & $25(10.7)$ & $284(2.0)$ & $<.001$ \\
\hline Newly requiring dialysis & $211(1.5)$ & $19(8.1)$ & $192(1.4)$ & $<.001$ \\
\hline Perioperative myocardial infarction & $102(0.7)$ & $1(0.4)$ & $101(0.7)$ & 1.00 \\
\hline Cardiac tamponade & $103(0.7)$ & $4(1.7)$ & $99(0.7)$ & .090 \\
\hline Transient ischemic attack & $134(0.9)$ & $9(3.8)$ & $125(0.9)$ & $<.001$ \\
\hline Atrial fibrillation & $1725(12.1)$ & $47(20.0)$ & $1678(12.0)$ & $<.001$ \\
\hline Anticoagulation-related complications & $46(0.3)$ & $4(1.7)$ & $42(0.3)$ & .007 \\
\hline Gastrointestinal bleeding & $137(1.0)$ & $15(6.4)$ & $122(0.9)$ & $<.001$ \\
\hline Inferior leg infection & $163(1.1)$ & $10(4.3)$ & $153(1.1)$ & $<.001$ \\
\hline Pneumonia & $246(1.7)$ & $23(9.8)$ & $223(1.6)$ & $<.001$ \\
\hline Urinary tract infection & $122(0.9)$ & $8(3.4)$ & $114(0.8)$ & $<.001$ \\
\hline Hospital stay (d) & $16(12-22)$ & $55(34-87)$ & $16(12-21)$ & $<.001$ \\
\hline Readmission $\leq 30 \mathrm{~d}$ & $298(2.1)$ & $14(6.0)$ & $284(2.0)$ & $<.001$ \\
\hline
\end{tabular}

Values are presented as $\mathrm{n}(\%)$ or median (interquartile range).

therefore, surgeons should make a concerted effort to shorten the operative time when conducting BITA grafting. Obesity was not an independent risk factor in the present study. This may be because the prevalence of overweight and obesity is lower in Asians (mean body mass index, 23-24) $)^{4,18,20,22}$ compared with that in Western populations (mean body mass index, 28-29). ${ }^{6,10}$

A recent subanalysis of the Arterial Revascularization Trial trial clearly demonstrated that a skeletonized BITA lowers the risk of DSWI compared with a pedicled

TABLE 4. Multiple logistic regression analysis of deep sternal wound infection

\begin{tabular}{lccr}
\hline \multicolumn{1}{c}{ Variables } & Odds ratio & $\begin{array}{c}\text { 95\% Confidence } \\
\text { interval }\end{array}$ & $\begin{array}{c}\boldsymbol{P} \\
\text { value }\end{array}$ \\
\hline Male & 0.57 & $0.42-0.77$ & $<.001$ \\
Diabetes mellitus & 2.13 & $1.59-2.85$ & $<.001$ \\
Renal failure & 1.80 & $1.37-2.38$ & $<.001$ \\
$\begin{array}{l}\text { Chronic lung disease } \\
\quad \text { moderate or greater }\end{array}$ & 2.19 & $1.13-4.25$ & .021 \\
Liver dysfunction & & & \\
Shock & 2.92 & $1.48-5.75$ & .002 \\
\hline Reoperation & 2.88 & $1.66-4.98$ & $<.001$ \\
Ejection fraction $<60 \%$ & 2.64 & $1.04-6.67$ & .041 \\
\hline Intra-aortic balloon pump & 1.54 & $1.16-2.04$ & .003 \\
\hline Operative time & 1.44 & $1.01-2.02$ & .043 \\
\hline
\end{tabular}

BITA. ${ }^{9}$ A limitation of the present study was that data on the harvesting technique were not available despite the skeletonization technique is widely available in Japan (Video 1). ${ }^{4,18,21}$ A rate of off-pump revascularization higher than $60 \%$ is another feature of CABG in Japan. ${ }^{4,13,20,21}$ The nonuse of cardiopulmonary bypass is expected to reduce the

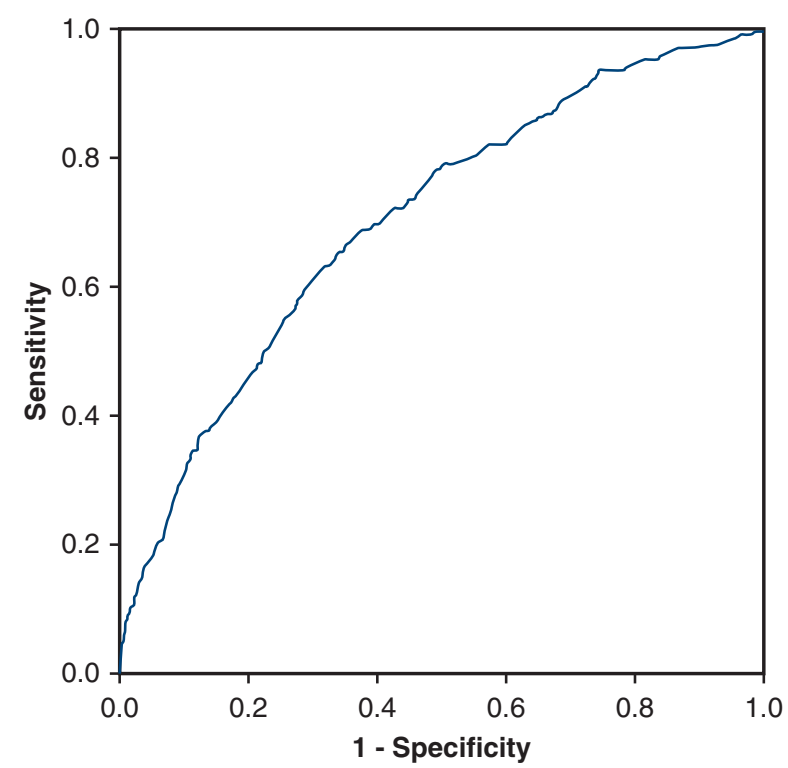

FIGURE 2. The areas under the receiver operating characteristic curve (AUC) for deep sternal wound infection. The AUC was 0.701. 


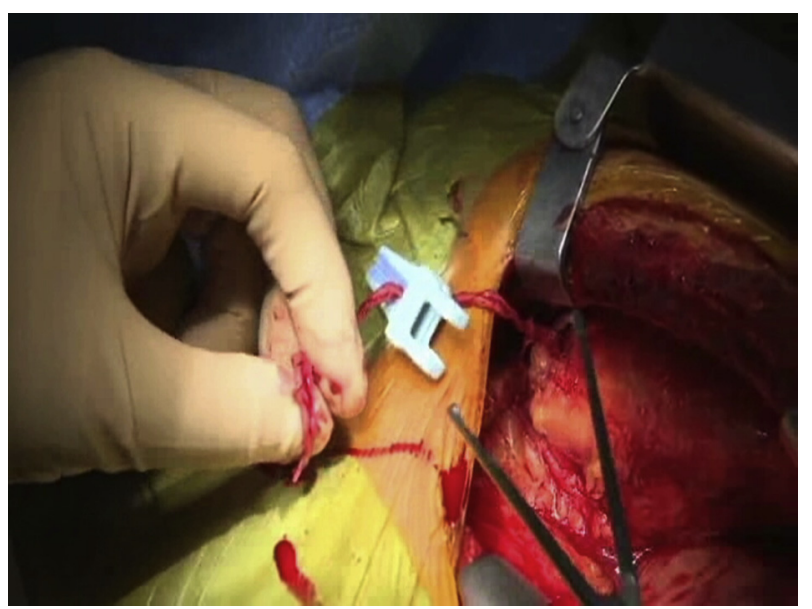

VIDEO 1. Bilateral internal thoracic artery (BITA) grafting with off-pump technique. Skeletonized BITA was harvested with using an ultrasound scalpel. Both grafts are long enough to reach targets. The in situ right ITA is anastomosed to the left anterior descending artery, and in situ left ITA is anastomosed to the posterolateral branch of the circumflex artery. Video available at: https://www.jtcvs.org/article/S0022-5223(18)32320-1/fulltext.

perioperative systematic inflammatory response; however, off-pump CABG was not identified as an independent factor to reduce DSWI. ${ }^{9,18}$

In the STS National Database, DSWI involves muscle, bone, and/or the mediastinum and must meet all of the 3 conditions specified in JACVSD definition (see Methods). Thus, if we applied the criteria of the STS National Database to the present study cohort, the number of DSWI cases in our cohort may be lower. However, it is not possible for us to identify the number of DSWI patients in the present study meeting the same criteria of the STS National Database.

We should note several limitations in this study. First, this was a retrospective study using a nationwide data-entry system. Second, a detailed breakdown of DSWI was not available, such as how many patients were treated solely with antibiotic agents, or underwent mediastinal drainage or sternal reconstruction. Third, detailed operative procedures, such as how ITA was harvested (pedicled or skeletonized) and how the ITA graft was utilized (in situ, free, or composite graft), were not available in JACVSD. Fourth, the exact number of patients not consenting to the data entry is unknown. Fifth, external validation using another database was difficult. Finally, JACVSD does not provide longterm data.

\section{CONCLUSIONS}

We reported the results and risks of DSWI after BITA grafting using a nationwide Japanese database. Although early outcomes of BITA grafting were acceptable, the incidences of hospital death and major morbidities after DSWI were higher than those without DSWI. The current data and risk model are informative to evaluate the risk of DSWI when performing BITA grafting.

\section{Conflict of Interest Statement}

Authors have nothing to disclose with regard to commercial support.

\section{References}

1. Lytle BW, Blackstone EH, Sabik JF, Houghtaling P, Loop FD, Cosgrove DM. The effect of bilateral internal thoracic artery grafting on survival during 20 postoperative years. Ann Thorac Surg. 2004;78:2005-12; discussion 2012-4.

2. Kieser TM, Lewin AM, Graham MM, Martin BJ, Galbraith PD, Rabi DM, et al. Outcomes associated with bilateral internal thoracic artery grafting: the importance of age. Ann Thorac Surg. 2011;92:1269-75; discussion 1275-6.

3. Raza S, Sabik JF, Masabni K, Ainkaran P, Lytle BW, Blackstone EH. Surgical revascularization techniques that minimize surgical risk and maximize late survival after coronary artery bypass grafting in patients with diabetes mellitus. $J$ Thorac Cardiovasc Surg. 2014;148:1257-64; discussion 1264-6.

4. Kinoshita T, Asai T, Suzuki T. Off-pump bilateral skeletonized internal thoracic artery grafting in patients with chronic kidney disease. J Thorac Cardiovasc Surg. 2015;150:315-21.e3.

5. Puskas JD, Sadiq A, Vassiliades TA, Kilgo PD, Lattouf OM. Bilateral internal thoracic artery grafting is associated with significantly improved long-term survival, even among diabetic patients. Ann Thorac Surg. 2012;94:710-5; discussion 715-6.

6. Tabata M, Grab JD, Khalpey Z, Edwards FH, O'Brien SM, Cohn LH, et al. Prevalence and variability of internal mammary artery graft use in contemporary multivessel coronary artery bypass graft surgery: analysis of the Society of Thoracic Surgeons National Cardiac Database. Circulation. 2009;120:935-40.

7. LaPar DJ, Crosby IK, Rich JB, Quader MA, Speir AM, Kern JA, et al. Bilateral internal mammary artery use for coronary artery bypass grafting remains underutilized: a propensity-matched multi-institution analysis. Ann Thorac Surg. 2015; 100:8-14; discussion 14-5.

8. Itagaki S, Cavallaro P, Adams DH, Chikwe J. Bilateral internal mammary artery grafts, mortality and morbidity: an analysis of 1526360 coronary bypass operations. Heart. 2013;99:849-53.

9. Benedetto U, Altman DG, Gerry S, Gray A, Lees B, Pawlaczyk R, et al. Pedicled and skeletonized single and bilateral internal thoracic artery grafts and the incidence of sternal wound complications: insights from the Arterial Revascularization Trial. J Thorac Cardiovasc Surg. 2016;152:270-6.

10. Benedetto U, Caputo M, Gaudino M, Marsico R, Rajakaruna C, Bryan A, et al. Right internal thoracic artery or radial artery? A propensity-matched comparison on the second-best arterial conduit. J Thorac Cardiovasc Surg. 2017;153:79-88.e4.

11. Dai C, Lu Z, Zhu H, Xue S, Lian F. Bilateral internal mammary artery grafting and risk of sternal wound infection: evidence from observational studies. Ann Thorac Surg. 2013;95:1938-45

12. Balachandran S, Lee A, Denehy L, Lin KY, Royse A, Royse C, et al. Risk factors for sternal complications after cardiac operations: a systematic review. Ann Thorac Surg. 2016;102:2109-17.

13. Ohira S, Doi K, Numata S, Yamazaki S, Kawajiri H, Yaku H. Impact of chronic kidney disease on long-term outcome of coronary artery bypass grafting in patients with diabetes mellitus. Circ J. 2016;80:110-7.

14. Vrancic JM, Piccinini F, Camporrotondo M, Espinoza JC, Camou JI, Nacinovich F, et al. Bilateral internal thoracic artery grafting increases mediastinitis: myth or fact? Ann Thorac Surg. 2017;103:834-9.

15. Gatti G, Soso P, Dell'Angela L, Maschietto L, Dreas L, Benussi B, et al. Routine use of bilateral internal thoracic artery grafts for left-sided myocardial revascularization in insulin-dependent diabetic patients: early and long-term outcomes. Eur J Cardiothorac Surg. 2015;48:115-20.

16. Kieser TM, Rose MS, Aluthman U, Montgomery M, Louie T, Belenkie I. Toward zero: deep sternal wound infection after 1001 consecutive coronary artery bypass procedures using arterial grafts: implications for diabetic patients. J Thorac Cardiovasc Surg. 2014;148:1887-95.

17. Aldea GS, Bakaeen FG, Pal J, Fremes S, Head SJ, Sabik J, et al. The Society of Thoracic Surgeons clinical practice guidelines on arterial conduits for coronary artery bypass grafting. Ann Thorac Surg. 2016;101:801-9.

18. Nakano J, Okabayashi H, Hanyu M, Soga Y, Nomoto T, Arai Y, et al. Risk factors for wound infection after off-pump coronary artery bypass grafting: should bilateral internal thoracic arteries be harvested in patients with diabetes? J Thorac Cardiovasc Surg. 2008;135:540-5.

19. Gatti G, Dell'Angela L, Barbati G, Benussi B, Forti G, Gabrielli M, et al. A predictive scoring system for deep sternal wound infection after bilateral internal thoracic artery grafting. Eur J Cardiothorac Surg. 2016;49:910-7. 
20. Saito A, Miyata H, Motomura N, Ono M, Takamoto S. Propensity-matched analysis of bilateral internal mammary artery vs single internal mammary artery in 7702 cases of isolated coronary artery bypass grafting. Eur J Cardiothorac Surg. 2013;44:711-7.

21. Ohira S, Doi K, Okawa K, Dohi M, Yamamoto T, Kawajiri H, et al. Safety and efficacy of sequential left internal thoracic artery grafting to left circumflex area. Ann Thorac Surg. 2016;102:766-73.

22. Ohira S, Miyata H, Doi K, Motomura N, Takamoto S, Yaku H. Risk model of aortic valve replacement after cardiovascular surgery based on a National Japanese Database. Eur J Cardiothorac Surg. 2017;51: 347-53.
23. Irie F, Iso H, Sairenchi T, Fukasawa N, Yamagishi K, Ikehara S, et al. The relationships of proteinuria, serum creatinine, glomerular filtration rate with cardiovascular disease mortality in Japanese general population. Kidney Int. 2005;69:1264-71.

24. De Paulis R, de Notaris S, Scaffa R, Nardella S, Zeitani J, Del Giudice C, et al. The effect of bilateral internal thoracic artery harvesting on superficial and deep sternal infection: the role of skeletonization. J Thorac Cardiovasc Surg. 2005 129:536-43.

Key Words: bilateral internal thoracic artery, coronary artery bypass grafting, deep sternal wound infection

Readers who found these articles interesting may also like to read the following papers found in recent and future issues of our sister publications, Seminars in Thoracic and Cardiovascular Surgery and Operative Techniques in Thoracic and Cardiovascular Surgery!

\section{Adult: Coronary}

ORIGINAL SUBMISSION: Remote Ischemic Preconditioning in High Risk Cardiovascular Surgery Patients: A RandomizedControlled Trial. Nicole S. Coverdale. Semin Thoracic Surg 2018: 26-33

Editorial Commentary: Remote Ischemic Preconditioning: A Complex Question with an Even More Complex Answer. Irving L. Kron. Semin Thoracic Surg 2018: 34-35 
TABLE E1. Preoperative and intraoperative variables for entry into the logistic regression model

\section{Preoperative variables}

Operation year (2013, 2014, or 2015)

Age

$$
\leq 60 \mathrm{y} \text { (reference) }
$$

$60-65$ y

$66-70$ y

$71-75$ y

$76-80 \mathrm{y}$

$>80 \mathrm{y}$

Sex

Smoking history

Smoking $\leq 1$ month before surgery

Diabetes mellitus

Diabetes mellitus with treatment

Renal failure

Dialysis

Estimated glomerular filtration rate $\leq 30 \mathrm{~mL} / \mathrm{min} / 1.73 \mathrm{~m}^{2}$

Hyperlipidemia

Hypertension

Cerebrovascular disease

Recent cerebrovascular disease ( $\leq 2 \mathrm{wk})$

Carotid stenosis

Carotid stenosis, bilateral

Chronic lung disease

$$
\begin{aligned}
& \geq \text { Moderate } \\
& \geq \text { Mild }
\end{aligned}
$$

Liver dysfunction

Extracardiac arterial disease

Peripheral artery disease

Thoracic aortic disease

Percutaneous coronary intervention

Old myocardial infarction

Congestive heart failure

Cardiogenic shock

Atrial fibrillation

Cardiac catheterization

Reoperation

Body mass index

$$
\begin{aligned}
& \geq 30 \\
& \geq 35
\end{aligned}
$$

New York Heart Association functional class

$$
4
$$

$\geq 3$

Canadian Cardiovascular Society grade

4

3

$\geq 3$

Number of diseased vessels

3

$\geq 2$

Left main disease

Left ventricular ejection fraction

$$
\begin{aligned}
& \leq 30 \% \\
& \leq 60 \%
\end{aligned}
$$

Aortic stenosis
TABLE E1. Continued

Mitral stenosis

Tricuspid stenosis

Pulmonary stenosis

Aortic insufficiency

Mitral insufficiency

Immunosuppression agent

Digitalis

Beta blockers

Intravenous nitrates

Inotropic agents

Aspirin

Other antiplatelets

Anticoagulants

Steroids

Intra-aortic balloon pump

Intraoperative variables

Operation time

Transfusion

Right radial harvest

Left radial harvest

Gastroepiploic artery harvest

Saphenous vein graft harvest

Off-pump

Number of distal anastomosis 